\section{Shouldering the burden}

A new approach to shoulder pain

\begin{tabular}{|c|c|c|}
\hline $\begin{array}{l}\text { The work of Professor } \\
\text { Richard Page and Dr Stephen } \\
\text { Gill, the Barwon Centre for } \\
\text { Orthopaedic Research and } \\
\text { Education (B-CORE), uses } \\
\text { sophisticated and modern } \\
\text { technologies to examine gene } \\
\text { expression and molecular } \\
\text { pathways in painful conditions } \\
\text { of the shoulder, including } \\
\text { frozen shoulder. Ultimately, } \\
\text { they hope to improve quality } \\
\text { of life and treatment outcomes } \\
\text { for people of all ages suffering } \\
\text { from musculoskeletal pain } \\
\text { such as shoulder pain } \\
\text { from tendon disease or } \\
\text { osteoarthritis. In addition, } \\
\text { Professor Page and Dr Gill } \\
\text { use biobanking to answer } \\
\text { questions regarding the cause, } \\
\text { mechanism and progression of } \\
\text { musculoskeletal conditions. }\end{array}$ & $\begin{array}{l}\text { ainful musculoskeletal conditions } \\
\text { are highly prevalent in the } \\
\text { community and are associated } \\
\text { with significant disability and health } \\
\text { burden. Conditions affecting the } \\
\text { shoulder have a high prevalence and } \\
\text { impact on a wide range of age groups } \\
\text { and common activities, with up to one } \\
\text { in twenty patients presenting to their } \\
\text { GP with shoulder pain. } \\
\text { Adhesive capsulitis (AC), or frozen } \\
\text { shoulder, is just one of a range of } \\
\text { common conditions affecting the } \\
\text { shoulder and its prevalence in the } \\
\text { general population is around } 2 \% \text {. The } \\
\text { disorder presents as stiffness, pain and } \\
\text { dysfunction of the ball and socket joint } \\
\text { of the shoulder called the glenohumeral } \\
\text { joint. It is often accompanied by issues } \\
\text { with the surrounding rotator cuff } \\
\text { muscles. AC is most common in women } \\
\text { and those aged } 40-60 \text {. While AC is } \\
\text { often self-limiting and may resolve } \\
\text { within two years in some people, it } \\
\text { can cause ongoing problems for many } \\
\text { individuals, particularly in diabetics. } \\
\text { Although much is known about how } \\
\text { AC presents, less is known about the } \\
\text { underlying causes of the condition, } \\
\text { and it is this that Professor Richard } \\
\text { Page, with collaborator Dr Stephen } \\
\text { Gill, hopes to learn more about. } \\
\text { Adhesive capsulitis is associated } \\
\text { with rotator cuff disease, a number } \\
\text { of other endocrinopathies and } \\
\text { trauma, suggesting a metabolic } \\
\text { or inflammatory common } \\
\text { pathway in the pathogenesis. } \\
\text { Indeed, it has been suggested } \\
\text { that secondary AC may be } \\
\text { associated with a history } \\
\text { of trauma or surgery, } \\
\text { heart attack or } \\
\text { diabetes. The } \\
\text { prevalence in } \\
\text { diabetes has been } \\
\text { cited as high as }\end{array}$ & $\begin{array}{l}\text { The prospective, longitudinal, multi- } \\
\text { centre study will be conducted at two } \\
\text { large regional hospitals in Victoria, } \\
\text { Australia and the researchers aimed to } \\
\text { recruit a minimum of } 25 \text { participants per } \\
\text { group. In order to be part of the study, } \\
\text { subjects will meet a strict set of criteria. } \\
\text { TRANSCRIPTOMICS } \\
\text { Professor Page's work includes looking } \\
\text { at transcriptome-wide alterations in } \\
\text { gene expression in the shoulder joints } \\
\text { of people with AC compared to those } \\
\text { who have shoulder robblems, but } \\
\text { lack inflammation. The transcriptome } \\
\text { represents the first step in gene } \\
\text { expression and involves copying the } \\
\text { DNA of a particular gene to make an } \\
\text { RNA molecule. By examining which } \\
\text { genes are being transcribed, we get } \\
\text { a picture of which genes are most } \\
\text { active under specific conditions. For } \\
\text { example, although we have genes } \\
\text { for many different hair colours, colour } \\
\text { is determined by which genes are } \\
\text { selectively transcribed and expressed } \\
\text { in that individual. }\end{array}$ \\
\hline
\end{tabular}

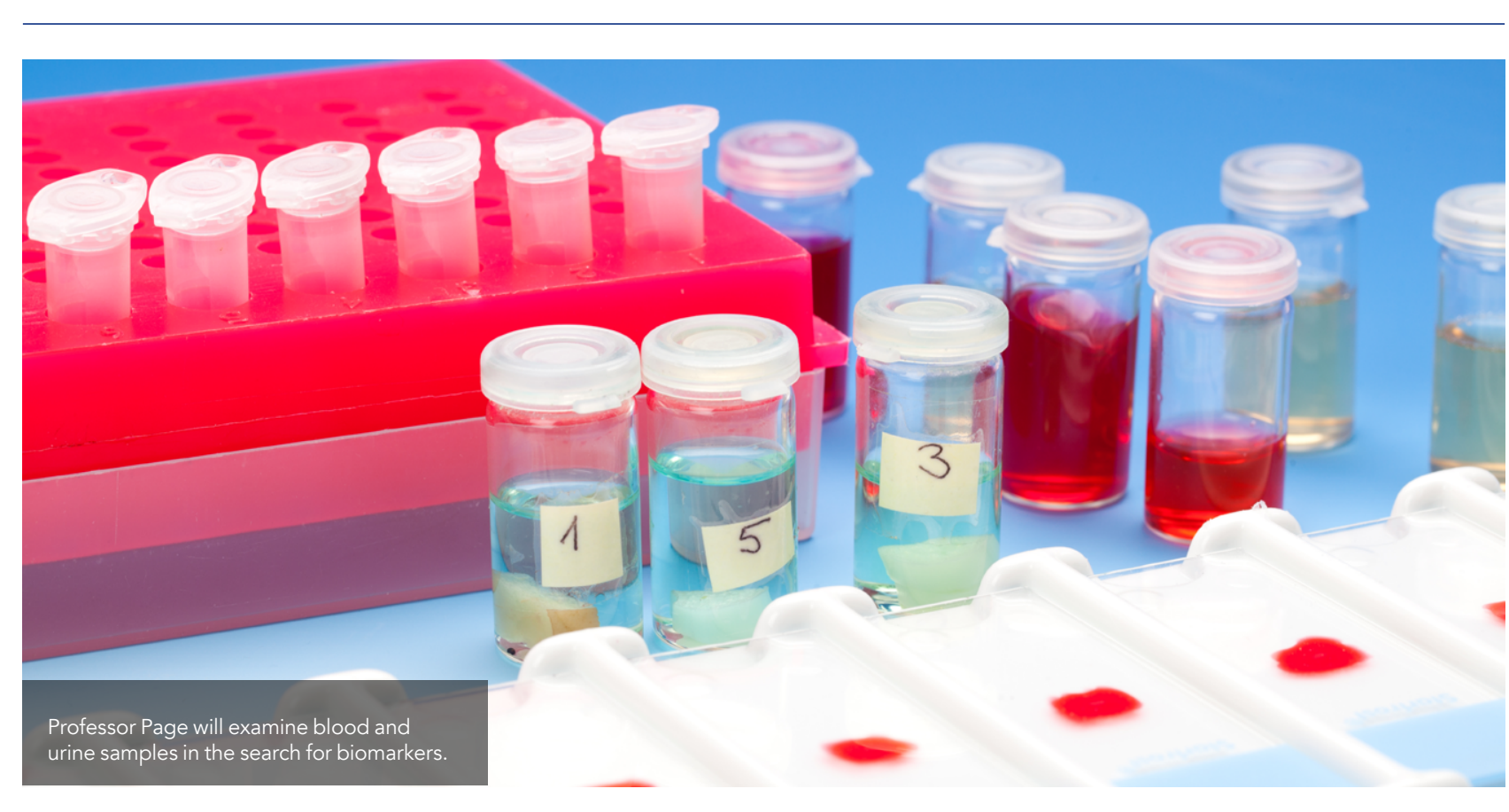

how gene expression influences $A C$ The AdCaB protocol paper is the starting point for a suite of studies looking at musculoskeletal gene expression.

\section{BIOMARKERS}

The second part of Professor Page's AdCaB study protocol is to search for serum and urine biomarkers to help further understand the diagnosis and stage of AC. Biomarkers, or biological markers, consistently appear in particular circumstances, such as a specific disease or physiological process.

In order to do this, blood and urine samples will be collected before subjects undergo surgery, and tissue samples will be collected during the from the samples and genome sequencing technology will be used to determine which genes are being expressed. Once genes have been identified, the team will conduct oth analyses, such as pathway analysis, which explores the biological pathw in which the genes are involved.

Furthermore, in order to identify potential biomarkers, computationa techniques will be used to identify which genes are most commonly seen in AC patients. Professor Page hopes that this will allow characterisation of groups of genes which could guide diagnosis of AC for future patients, as well as shedding light on the
underlying mechanisms of disease.
Understanding disease pathways represents an important step towards these mechanisms.

CLINICAL OUTCOMES will explore joint surgery outcom in people with AC. Patient-

reported outcome measures will

be collected before surgery, and

at three and 12 months after surgery. The measures to be collected by Orthopaedics will include the Oxford Shoulder Score and the Oxford Shoulder Instability Score. The pre and post-operative data will be analysed with statistical software, taking into account factors such as age and whether participants are right or left-

Painful musculoskeletal conditions, such as those affecting the shoulder are highly prevalent in the community and are associated with significant disability and health burden.

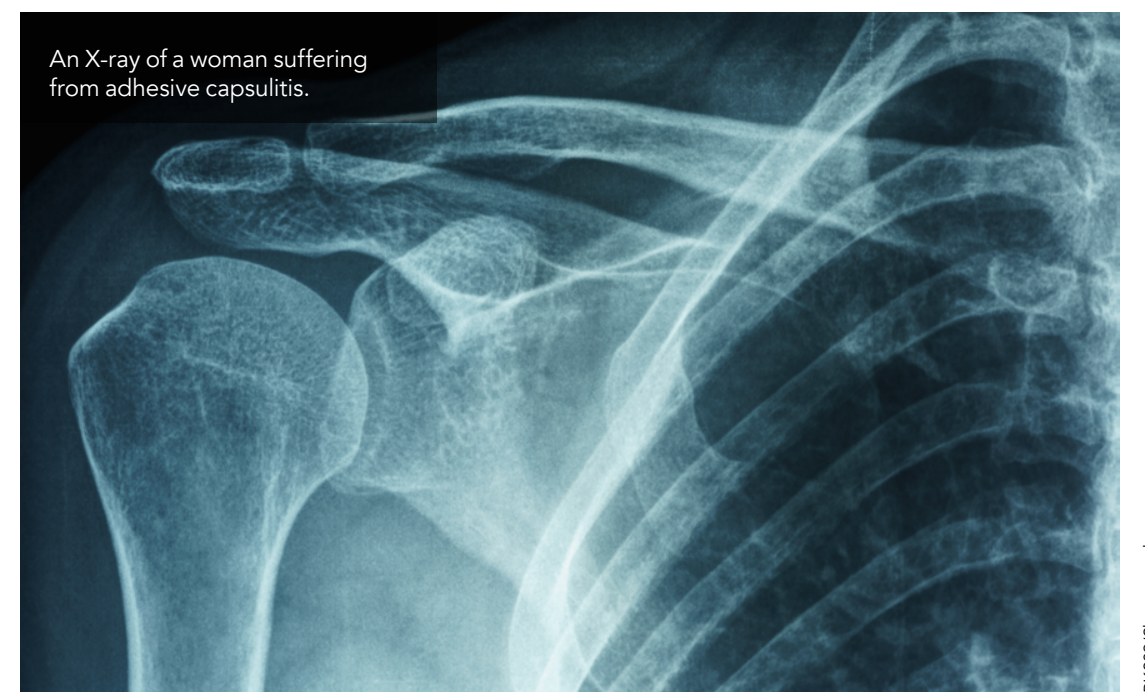

The third part of the AdCaB study 


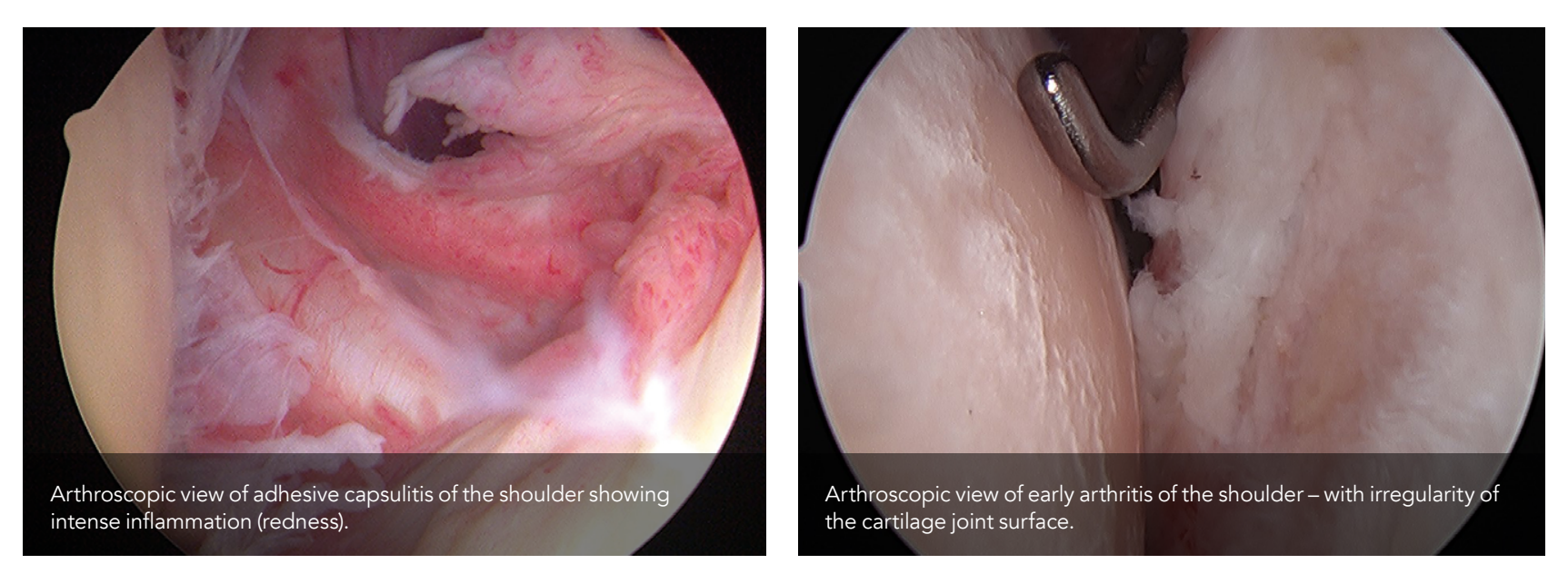

BIOBANKING

management of challenging joint The broader aim of Professor Page's treatment of cove the diagnosis and the shoulder, as well as athering musculoskeletal conditions One this is through linking the research data to the Barwon Joint Registry in

replacement infections. The researchers are using this tissue banking platform to investigate a range of conditions from osteoarthritis, joint instablity, frozen shoulder and jint replacent infections. As well as exploring the conditions themselves, Professor Page

The $A d C a B$ protocol paper is the starting point for a suite of studies looking at musculoskeletal gene expression.

Australia, a database for evaluating outcomes of joint replacement surgery, to enable the follow up of patient treatment outcomes.

As part of this work, tissue and blood samples are being collected from joint replacementingections with the ain to future patients. This bis of may a so yield potentia biong that can improve the diagnosis and

is also interested in the links to systemic whabolic conditions, such as diabetes, which affect patients.

These studies recruit from a surgic cohort and involve the collection of tissue nomally excised and discarded at surgery, as well as blood and urine during surgery eliminates addition injury or discomfort to participants. These studies will increase knowledg

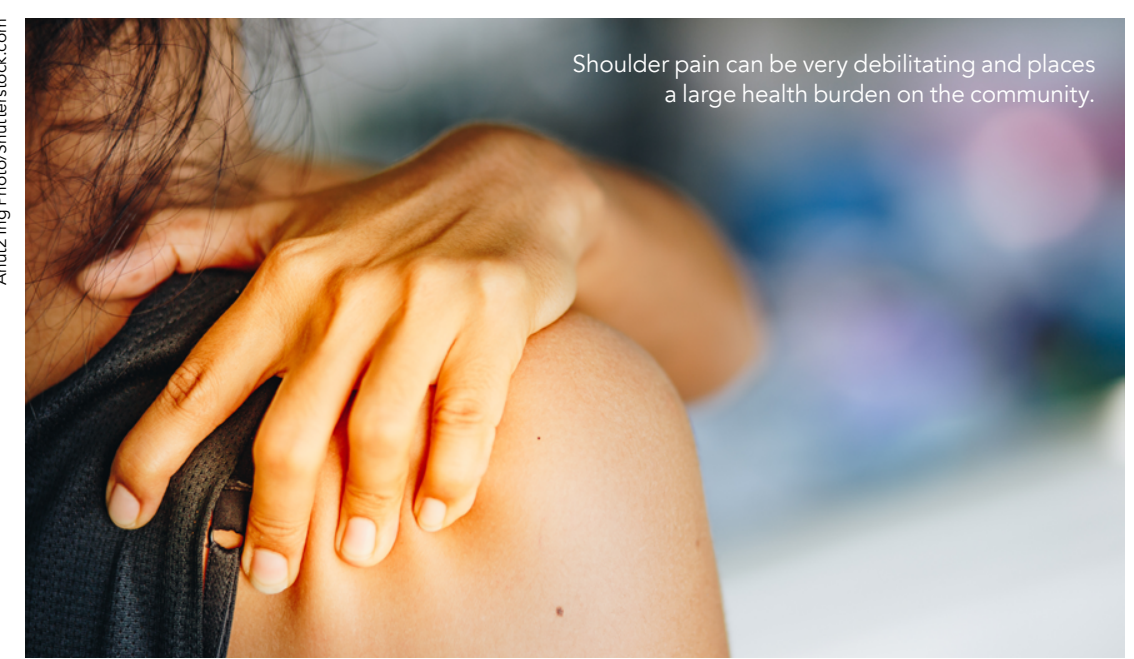

about transcriptome expression and molecular pathways underlying these disease processes. In doing so, the researchers hope to identify novel biomankers, leading to earlier diagnosis and optimisation of treatment conditions, including frozen shoulder and shoulder arthritis.

\section{PRELIMINARY RESULTS}

the AdCaB study show that the group at B-CORE and Geelong Orthopaedics were able to recruit 22 patients to the AC group and 26 patients to the control group. They were able to identify 545 genes whic were differentially expressed in $A C$ either significantly up or down-regulated compared to controls. As expected, the genes which were up-regulated included those linked to inflammatory processes and collagen and bone cel synthesis. However, the group did jentify some novel genes which had including potential vitamin C-dependen pathways. Analyses are still ongoing, with the next steps involving processing the serum and urine samples, as well as doing sub-analyses for risk groups such as age, gender and those with diabetes.

Linking this work to the rotator cuff and shoulder osteoarthritis research being done by Professor Page, Dr Gill and colleagues will provide new information about the pathogenesis (mechanism of disease), diagnosis and staging of $A C$, as well as evaluating clinica outcomes of people who undergo shoulder surgery. In addition, screening for diagnostic biomarkers will lead to a more directed and timely treatment for
sufferers of this debilitating condition.

\section{Behind the Research}

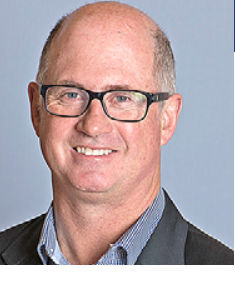

Richard Page

E: Richard.page@deakin.edu.au @BCORE5

W: http://bcore.deakin.edu.au W: :ttps://www.deakin.edu.au/about-deakin/people/richard-page W: http://geelongorthopaedics.surgery/prof-richard-page

\section{Research Objectives}

Professor Richard Page and Dr Stephen Gill use a new approach to better understand musculoskeletal conditions.

\section{Detail}

Barwon Centre for Orthopaedic Research and Education non and Rearch Centre

Hospital Geelong, Victoria, Australi

Bio

Thard Page is an orthopaedic shoulder surgeon with over is the Founding Director of B-CORE, St John of God and has been Barwon Health Chair of Orthopaedics at Deaki University since 2014. His interests include outcomes of shoulder and upper limb surgery, osteoarthritis and joint replacem

Stephen Gill is a clinician-researcher who assists Professo Page to develop and implement B-CORE's research programs. Since completing his $\mathrm{PhD}$ in 2009, Stephen musculoskeletal research. He continues to work as a sentor clinician physiotherapis.

Funding

- Barwon Health - Education, Training

and Research Profile Fund

Collaborators

Deakin University - Centre for Molecular

and Medical Research

and

- St John of God Hospital Geelong https://www.sjog.org.au/our-locations/st-john-of-godgeelong-hospital

- Barwon Health

https://www.barwonhealth.org.au

- Geelong Orthopaedics

https./Iwww.geelongorthopaedics group.com.au

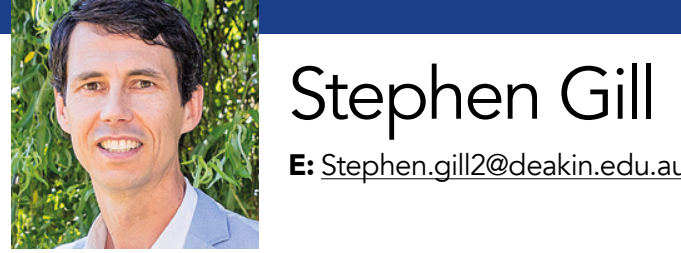

W: https://www.deakin.edu.au/about-deakin/ people/stephen-gill

\section{References}

Page, S. R., McGee, S. L., Eng, K., Brown, G., Beattie, S., Collier, F. \& Gill, S. D. (2019). Adhesive capsulitis of the shoulder. protocol for the adhesive capsulitis biomarker Atps//doiorg/101186/s12891019-2536-x

Ackerman I. N., Page R. S., Fotis K., et al. Exploring the personal burden of shoulder pain among younger people in Australia: protocol for a multicentre cohort study. BMJOPEN 2018021859

Kamal N., McGee S. L., Brown G., Beattie S., Eng K., Collier F., Gill S., Page R. Transcriptomic analysis of adhesive capsulitis of the shoulder. Gene Expression Omnibus (GEO). 20 Nov 2019 https://www.ncbi.nlm.nih.gov/geo/query/acc.

Personal Response

Do you have any new results from the $A d C a B$ study

II We compared the genes from the tissue of patients with adhesive capsulitis (AC) with those having surgery for shoulde $A C$. Tissue te de specific to AC. Tissue samples were collected during su
the RNA was extracted, and RNA-sequencing-based transcriptomics undertaken (using Next Gen Sequencin We then analysed the results to identify biological processes and pathways that were active. When we spotted a number of genes that seemed to be differentially expressed, these were validated using a process known as real time RT-PCR,

The results showed that patients with AC had increased expression of three genes (PDGFB, COL18A1 and MMP9) has identified interesting and novel pathways to enhance our understanding of $A C$ and provided potential future targets for staging and treatment of this painful and debilitating shoulder condition. 